\title{
PENGARUH SISTEM OLAH TANAH DAN PEMUPUKAN NITROGEN JANGKA PANJANG TERHADAP LAJU INFILTRASI TANAH PADA TANAMAN JAGUNG (Zea mays L.) DI LAHAN POLITEKNIK NEGERI LAMPUNG
}

\author{
PENGARUH SISTEM OLAH TANAH DAN PEMUPUKAN NITROGEN \\ JANGKA PANJANG TERHADAP LAJU INFILTRASI TANAH PADA TANAMAN \\ JAGUNG (Zea mays L.) DI LAHAN POLITEKNIK NEGERI LAMPUNG
}

\author{
Pranata Arwan Dinu*, Muhajir Utomo, Afandi, dan Irwan Sukri Banuwa \\ Jurusan Agroteknologi, Fakultas Pertanian, Universitas Lampung \\ J1 Sumantri Brojonegoro 1, Bandar Lampung 35145, Indonesia \\ *Email:Pranataa40@gmail.com
}

\section{ABSTRACT}

This study aims to determine the effect of tillage systems and the effects of long-term nitrogen fertilization and their interactions on soil infiltration rate. This research is a 32-year long-term research conducted in November 2018 to February 2019 in the land of the Lampung State Polytechnic. The research is a factorial experiment (2x3) arranged in a randomized block design (RCBD) with 3 replications. The first factor is nitrogen fertilizationwith dose of $0 \mathrm{~kg} \mathrm{~N} \mathrm{ha}^{-1}$ (N0) and $200 \mathrm{~kg} \mathrm{~N} \mathrm{ha}^{-1}$ (N2). The second factor is the tillage systems, there areintensive tillage (IT), minimum tillage (MT), and no tillage (NT). Observation variables include soil infiltration rate, soil organic $C$, bulk density, soil porosity, and root dry weight. The results show that the soil infiltration rateisaffected either by the tillage system and nitrogen fertilization but there is not interaction between the two treatments.the fastest rate ofsoil infiltration is in the combination of intensive tillage treatment and nitrogen fertilization (N2IT).

Keywords: Nitrogen fertilization, soil infiltration rate, tillage system.

\begin{abstract}
ABSTRAK
Penelitian ini bertujuan untuk mengetahui pengaruh sistem olah tanah dan pengaruh pemupukan nitrogen jangka panjang serta interaksinya terhadap laju infiltrasi tanah. Penelitian ini merupakan penelitian jangka panjang tahun ke-32 yang dilaksanakan pada bulan November 2018 sampai Februari 2019 di lahan Politeknik Negeri Lampung. Penelitian ini disusun secara faktorial (2x3) dalam rancangan acak kelompok (RAK) dengan 3 ulangan. Faktor pertama adalah dosis pemupukan Nitrogen dengan0 $\mathrm{kg} \mathrm{N} \mathrm{ha}^{-1}\left(\mathrm{~N}_{0}\right)$ dan $200 \mathrm{~kg} \mathrm{~N} \mathrm{ha}^{-1}\left(\mathrm{~N}_{2}\right)$. Faktor kedua adalah sistem olah tanah yaitu Olah Tanah Intensif(OTI), Olah Tanah Minimum (OTM), dan Tanpa Olah Tanah (TOT). Variabel pengamatan meliputi Laju infiltrasi tanah, C-organik tanah, Berat volume tanah, Porositas Tanah dan Bobot kering akar. Hasil penelitian menunjukkan bahwa laju infiltrasi tanah dipengaruhi oleh sistem olah tanah dan pemupukan nitrogen namun tidak terjadi interaksi antara kedua perlakuan. Laju infiltrasi tanah tercepat adalah pada kombinasi perlakuan olah tanah intensif dan pemupukan nitrogen (N2T1).

Kata kunci: Laju infiltrasi tanah, pemupukan nitrogen, sistem olah tanah.
\end{abstract}




\section{PENDAHULUAN}

Jagung merupakan komoditas pangan setelah padi yang memiliki peranan cukup penting di Indonesia. Hal ini ditunjukan oleh tingginya produksi jagung di Indonesia. Badan Pusat Statistik (BPS) mulai tahun 2014 hingga 2019 mencatat produksi jagungdi Indonesia mengalami tren peningkatan mencapai 28,9 juta ton (BPS,2015).

Sebagian besar petani di Indonesia mengusahakan varietas jagung hibrida, karakteristik varietas jagung hibrida adalah tanggap terhadap pemupukan dan cocok ditanam di lahan subur dengan produktifitas tinggi. Namun, diperkirakan 59\% pertanaman jagung di Indonesia diusahakan di lahan Ultisol yang tidak subur. Lahan Ultisol mempunyai masalah fisika dan kimia tanah, sehingga jagung yang ditanam di lahan Ultisol pertumbuhannya terganggu dan produksinya rendah (Subandi, 2003).

Pada budidaya tanaman yang harus diperhatikan adalah pengolahan tanah. Pengolahan tanah dilakukan agar perakaran dapat tumbuh dengan baik dan kondisi air tanah dapat terpelihara dengan baik. Untuk memberdayakan tanah secara maksimum perlu teknik budidaya yang cocok dalam pemecahan masalah penggunaan lahan kering untuk tanaman semusim. Olah tanah konservasi merupakan salah satu pendekatan sistem produksi tanaman yang memperhatikan konservasi lahan(Utomo dkk, 2016).

Selain pengolahan tanah yang baik, untuk meningkatkan produksi tanaman jagung juga dapat dilakukan dengan pemupukan. Pemupukan dilakukan untuk menambahkan unsur hara kedalam tanah yang dapat meningkatkan pertumbuhan dan hasil produksi tanaman. Pengolahan tanah secara teratur dan pemupukan yang tepat dianggap sangat penting karena berpengaruh terhadap infiltrasi tanah dan sifat fisik lainnya. Infiltrasi tanah adalah peristiwa masuknya air ke dalam tanah. Banyaknya air yang masuk ke dalam tanah persatuan waktu melalui permukaan tanah disebut laju infiltrasi (Arsyad, 2010).

Laju infiltrasi yang efektif tidak hanya meningkatkan jumlah air yang tersimpan dalam tanah untuk pertumbuhan tanaman, tetapi dapat mengurangi erosi yang diaktifkan oleh run off. Laju infiltrasi di dalam tanah akan sangat menentukan jumlah air yang diinfiltrasikan dan jumlah run-off yang dialirkan.Untuk itu perlu dilakukan penelitian ini untuk mengetahui pengaruh sistem olah tanah dan pemupukan $\mathrm{N}$ terhadap laju infiltrasi tanah pada pertanaman jagung.

Berdasarkan latar belakang dan masalah yang telah dikemukakan, maka penelitianini bertujuan untuk : Mengetahui pengaruh sistem olah tanah dan pemupukan nitrogen terhadap laju infiltrasi tanah pada pertanaman jagung dan untuk mengetahui interaksi antara sistem olah tanah dan pemupukan $\mathrm{N}$ jangka panjang berpengaruh terhadap permeabilitas tanah pada tanaman jagung.

\section{BAHAN DAN METODE}

Penelitian ini merupakan penelitian jangka panjang tahun ke-32 dilakukan di kebun percobaan Politeknik Negeri Lampung yang terletak pada $105^{\circ} 13^{\prime} 45,5^{\prime \prime}-105^{\circ} 13$ '48,0' BT dan 05'21'19,6' 05'21'19,7' LS dengan elevasi $122 \mathrm{~m}$ di atas permukaan laut (Utomo, 2015). Tahun ke-30 semua plot OTK diolah kembali. Penelitian ini dilaksanakan 
pada bulan November 2018 sampai Febuari 2019. Analisis tanah dilakukan di Laboratorium Ilmu Tanah Fakultas Pertanian Universitas Lampung.

Penelitian dilaksanakan menggunakan Rancangan Acak Kelompok (RAK) yang disusun secara faktorial 2 x 3 dengan 3 ulangan. Faktor pertama adalah pemupukan nitrogen jangka panjang yaitu $\mathrm{N}_{0}=$ $0 \mathrm{~kg} \mathrm{~N} \mathrm{ha-1}$, dan $\mathrm{N}_{2}=200 \mathrm{~kg} \mathrm{~N} \mathrm{ha}$ han $^{-1}$, daktor kedua adalah sistem olah tanah jangka panjang yaitu $\mathrm{T}_{1}=$ Olah Tanah Intensif $(\mathrm{OTI}), \mathrm{T}_{2}=$ Olah Tanah Minimum(OTM), $\mathrm{T}_{3}=$ Tanpa Olah Tanah (TOT).Data yang diperoleh dari penelitian ini kemudian diuji homogenitasnya dengan Uji Bartlett dan adifitasnya dengan Uji Tukey. Setelah asumsi terpenuhi, data diolah dengan analisis ragam dan dilanjutkan dengan Uji Beda Nyata Terkecil (BNT) pada taraf $5 \%$.

Pemupukan yang digunakan pada penelitian ini adalah pupuk N (urea), P (SP36), dan K (KCL). Aplikasi pupuk $\mathrm{P}$ dan $\mathrm{K}$ dilakukan pada 1 minggu setelah tanam dengan dosis $100 \mathrm{~kg} \mathrm{SP} 36 \mathrm{ha}^{-1}$ dan 50 $\mathrm{kg} \mathrm{KCl} \mathrm{ha}{ }^{-1}$. Pupuk N diberikan dua kali, yaitu satu per tiga dosis pada saat jagung berumur satu minggu setelah tanam dan dua per tiga dosis pada saat jagung memasuki fase vegetatifmaksimum yakni delapan minggu setelah tanam. Pupuk diaplikasikan dengan cara dilarik.

Pemeliharaan meliputi penyulaman, penyiangan, serta pengendalian hama dan penyakit. Penyulaman dilakukan pada lubang tanam yang tidak tumbuh benih jagung dan dilaksanakan satu minggu setelah tanam. Penyiangan menggunakan herbisida dan mencabut, mengoret gulma yang tumbuh di petak percobaan.

Pengambilan sampel dilakukan pada plot dengan perlakuan tanpa olah tanah (T3), olah tanah minimum
(T2), dan olah tanah intensif(T1) yang dikombinasikan

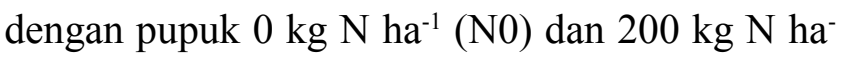
${ }^{1}(\mathrm{~N} 2)$. Pengambilan sampel dilakukan sekali yaitu saat pemanenan tanaman. Sampel tanah yang telah diambil dikering anginkan dan dianalisis di laboratorium fisika tanah, variabel utama dalam penelitian ini adalah laju infiltrasi, dan variabel pendukung pada penelitian ini adalah C-organik, berat volume tanah, porositas tanah, dan bobot kering akar.

Mengukur laju infiltrasi tanah menurut Afandi (2019), menggunakan prosedur pengukuran sebagai berikut: (1) Ring pengukur dibenamkan secara vertical ke dalam tanah sedalam $15 \mathrm{~cm}$ (2) Pasang tabung luar pada kedalaman yang sam, (3) Ambil sampel untuk kadar air tanah sampai kedalaman 0-15 cm, untuk mengetahui berapa kadar air tanah awal pada saat dilakukan pengukuran, (4) Pasang penggaris di dalam tabung dengan angka nol di permukaan tanah (5) Isi tabung bagian luar dengan air setinggi 10-12 cm(6) Isi tabungbagian dalam dengan ketinggianair sama dengan tabung luar sampai infiltrasi konstan, (7) Padatabung bagian dalam, dicatat tinggi air setiap interval turun pada interval tertentu, catat waktunya, tambahkan air sampai batas awal lagi setinggi $10 \mathrm{~cm}$ (8) Pengamatan dihentikan setelah dicapai laju infiltrasi yang relative konstan, yakni perbedaan laju infiltrasi tidak melebihi $10 \%$, (9) Pengamatan dilakukan minimal sampai 10 kali pengamatan (sekitar 80-120 menit), sehingga perhitungan infiltrasi dengan berbagai persamaan dapat dilakukan dengan baik.

Analisis data yang digunakan setelah data hasil pengukuran dengan menggunakan Double Ring Infiltrometer dalam penentuan laju infiltrasi yaitu 
menggunakan Model Persamaan Philip.

$$
i=0,5 S t^{-1 / 2}+A
$$

yakni :

i : : Laju Infiltrasi

S : Sorpsivitas $\left(\mathrm{mm} \mathrm{jam}^{-1}\right)$

$\mathrm{T}$ :Akumulasi waktu (menit)

A :Transmisivitas $\left(\mathrm{mmjam}^{-1}\right)$

Untuk menentukan kelas Infiltrasi dipakai klasifikasi menurut U.S Soil Conservation.

\section{HASIL DAN PEMBAHASAN}

\section{Berat Volume Tanah dan Porositas Tanah}

Pada Tabel 1, perlakuan sistem olah tanah dan pemupukan nitrogen tidak berpengaruh nyata terhadap berat volume tanah dan porositas tanah. Hal ini diduga karena mulsa yang berasal dari gulma dan residu seresah tanaman yang diberikan terlalu sedikit yaitu hanya sebesar 6-8 ton/ha (Utomo, 2015). Mulyani (2003), menyatakan bahwa pemberian bahan organik dari tanaman penutup tanah yang dibenamkan kedalam tanah baru dapat meningkatkan porositas total tanah dan mempertahankan kandungan bahan organik tanah serta meningkatkan efisiensi pemupukan anorganik.

Menurut Utomo (2015), pengolahan tanah berakibat pada peningkatan aerasi sehingga pelapukan bahan organik tanah yang menghasilkan gas $\mathrm{CO} 2$ pun meningkat. Untuk menurunkan berat volume tanah, meningkatkan porositas dan ruang pori diperlukan mulsa sisa tanaman lebih dari 11 ton ha-1. Seperti diketahui, olah tanah konservasi pada tahun ke-30 diolah kembali, sehingga menurunkan berat volume tanah dan meningkatkan porositas tanah.

Tabel 1. Rekapitulasi analisis ragam pengaruh sistem olah tanah dan pemupukan $\mathrm{N}$ terhadap sifat tanah

\begin{tabular}{ccccc}
\hline \multirow{2}{*}{ No } & Variabel penelitian & \multicolumn{3}{c}{ Hasil Uji F 5\% } \\
\cline { 3 - 4 } & Porositas & OT & PN & OT x PN \\
\hline 1. & Berat Volume Tanah & th & th \\
2. & Bobot Kering Akar & th & th & th \\
3. & Karbon Organik Tanah & $*$ & $*$ & tn \\
4. & Kn
\end{tabular}

Keterangan : $*=$ Berbeda nyata pada uji $\mathrm{F}$ taraf $5 \%$, tn $=$ Tidak berbeda nyata pada uji $\mathrm{F}$ taraf $5 \%$, OT $=$ Olah Tanah, $\mathrm{PN}=$ Pemupukan Nitrogen.

Tabel 2. Berat volume tanah, porositas tanah, kadar air volumetrik, dan bobot kering akar akibat penerapan berbagai sistem olah tanah dan pemupukan nitrogen.

\begin{tabular}{ccccc}
\hline Perlakuan & $\begin{array}{c}\text { Berat Volume Tanah } \\
\left(\mathrm{g} \mathrm{cm}^{-3}\right)\end{array}$ & $\begin{array}{c}\text { KA Volumetrik } \\
(\%)\end{array}$ & Porositas $(\%)$ & $\begin{array}{c}\text { Bobot Kering Akar } \\
\left(\mathrm{g} \mathrm{tan}^{-1}\right)\end{array}$ \\
\hline N0T1 & 1,02 & 34,24 & 57,73 & 21,62 \\
N0T2 & 1,02 & 33,77 & 59,30 & 21,44 \\
N0T3 & 0,99 & 37,83 & 57,71 & 37,34 \\
N2T1 & 1,02 & 34,68 & 57,68 & 36,95 \\
N2T2 & 1,03 & 39,06 & 57,06 & 26,35 \\
N2T3 & 1,00 & 35,34 & 57,53 & 50,62 \\
\hline
\end{tabular}

Keterangan : $\mathrm{N} 0=0 \mathrm{~kg} \mathrm{Nha}^{-1}, \mathrm{~N} 1=200 \mathrm{~kg} \mathrm{~N} \mathrm{ha}^{-1}, \mathrm{~T} 1=$ Olah tanah intensif, $\mathrm{T} 2=$ Olah tanah minimum, $\mathrm{T} 3=$ Tanpa olah tanah. 


\section{Bobot Kering Akar}

Tabel 2 menunjukkan bobot kering akar pada perlakuan pemupukan nitrogen $200 \mathrm{~kg} \mathrm{~N} \mathrm{ha}^{-1}$ lebih tinggi dibandingkan dengan perlakuan tanpa pemupukan nitrogen. Hal ini terjadi karena pemupukan nitrogen mengakibatkan pemakaian nitrogen oleh tanaman dan organisme tanah lebih banyak.Pada perlakuan sistem olah tanah, nilai bobot kering akar tertinggi pada perlakuan tanpa olah tanah dibandingkan dengan olah tanah lainnya. Hal tersebut diduga karena tanaman mendapatkan nitrogen lebih banyak pada perlakuan tanpa olah tanah. Menurut Wahyunie(2012), kelebihan yang dihasilkan oleh sitem pengolahan tanah konservasi adalah meningkatkan kandungan bahan organik, meningkatkan ketersediaan air dalam tanah, memperbaiki kegemburan dan porositas tanah. Hal tersebut sejalan dengan pernyataan Utomo (2015), pada olah tanah konservasi, serasah dan residu tanaman pada musim sebelumnya dimanfaatkan sebagai mulsa di lahan menyebabkan nitrogen ditanahmenjaditidakmudah hilang karena proses dekomposisi bahan organik lebih lambat.

\section{Karbon Organik Tanah}

Berdasarkan uji BNT taraf $5 \%$ pada Tabel 3 menunjukkan bahwa perlakuan sistem olah tanah dan pemupukan nitrogen jangka panjang memberikan pengaruh yang nyata pada kandungan karbon organik tanah. Sistem olah tanah intensif memiliki kandungan karbon organik tanah terendah yaitu sebesar 1,53\% dan berbeda nyata dengan sistem olah tanah yang lainnya. Rendahnya kandungan karbon organik pada sistem olah tanah intensif disebabkan gulma dan residu tanaman pada olah tanah intensif disingkirkan dari lahan pertanaman, sehingga lahan tidak mendapat tambahan sumber bahan organik. Selain itu, pengolahan tanah secara intensif akan mempercepat proses dekomposisi bahan organik yang akhirnya dapat menyebabkan penurunan bahan organik tanah (Rachman,dkk.,2015).

Sistem olah tanah minimum dan tanpa olah tanah memiliki kandungan bahan organik yang tinggi yaitu sebesar $1,68 \%$ dan $1,66 \%$ sementara sistem olah tanah intensif hanya sebesar 1,53\%. Hal ini disebabkan pada olah tanah minimum dan tanpa olah tanah, gulma dan residu tanaman sebelumnya dikembalikan pada lahan pertanaman, sehingga menjadi sumber bahan oranik tanah. Gulma dan sisa-sisa tanaman pada musim tanam sebelumnya digunakan untukmenutupi permukaan tanah, agar menjaga kelembaban dan aerasi yang baik, serta menyimpan airuntuk kebutuhan tanaman (Utomo, 2015).

Tabel 3. Pengaruh sistem olah tanah dan pemupukan N terhadap Karbon Organik Tanah.

\begin{tabular}{ccc}
\hline & Perlakuan & Karbon Organik Tanah (\%) \\
\hline \multirow{2}{*}{ Sistem olah tanah } & Olah Tanah Intensif & $1,53 \mathrm{~b}$ \\
& Olah Tanah Minimum & $1,68 \mathrm{a}$ \\
& Tanpa Olah Tanah & $1,66 \mathrm{a}$ \\
\hline BNT 5\% & 0,12 \\
\hline \multirow{2}{*}{ Pemupukan Nitrogen } & $0 \mathrm{~kg} \mathrm{~N} \mathrm{ha}^{-1}$ & $1,69 \mathrm{a}$ \\
& $200 \mathrm{~kg} \mathrm{~N} \mathrm{ha}^{-1}$ & $1,55 \mathrm{~b}$ \\
\hline BNT 5 \% & & 0,10 \\
\hline
\end{tabular}

Keterangan : Nilai tengah pada kolom yang diikuti huruf yang sama tidak berbeda nyata menurut uji BNT pada taraf $5 \%$. 
Pada penelitian ini, perlakuan pemupukan nitrogen memberikan pengaruh yang nyata terhadap kandungan karbon organik tanah. Tetapi pemupukan nitrogen dengan dosis $200 \mathrm{~kg} \mathrm{~N}$ ha ${ }^{-1}$ memiliki kandungan bahan organik lebih rendah dibandingkan dengan tanpa pemupukan nitrogen. Hal tersebut diduga akibat pemupukan nitrogen dengan dosis $200 \mathrm{~kg} \mathrm{~N}$ ha $^{-1}$ jangka panjang memacu penurunan bahan organik tanah sehingga karbon yang tersisa semakin sedikit dibandingkan dengan tanpa pemupukan nitrogen. Hal ini sejalan dengan penelitian Diara (2017), yang menyatakan bahwa penggunaan pupuk kimia (urea) yang diberikan secara terus menerus pada setiap musim tanam dapat mengakibatkan terjadinya degradasi kandungan karbon organik tanah.

Utomo dkk (2016), menyatakan bahan organik tanah memiliki pengaruh positif terhadap sifat kimia, fisik dan biologi dari tanah. Jumlah bahan organik di dalam tanah diperkirakan hanya berkisar 5\% dari total volume tanah, tetapi berpengaruh terhadap sebagian besar sifat tanah. Pengaruh menguntungkan dari bahan organik tanah diantaranya meningkatkan struktur dan agregasi tanah, meningkatkan presentasi ruang pori tanah, dan meningkatkan kapasitas tanah untuk menahan air, juga meningkatkan kekuatan air terikat di dalam tanah.

\section{Laju Infiltrasi}

Tabel 4 menunjukkan sistem olah tanah dan pemberian pupuk nitrogen menunjukan pengaruh yang signifikan terhadap laju infiltrasi tanah, sedangkan interaksi antara sistem olah tanah dan pemupukan nitrogen tidak memberikan pengaruh yang signifikan terhadap laju infiltrasi.

Kecepatan laju infiltrasi pada perlakuan olah tanah intensif sebesar 56,61 $\mathrm{cm} \mathrm{jam}^{-1}$, pada perlakuan olah tanah minimum $36,81 \mathrm{~cm} \mathrm{jam}^{-1}$ dan pada perlakuan tanpa olah tanah 25,35 $\mathrm{cm} \mathrm{jam}^{-1}$. Hal ini diduga karena pada perlakuan olah tanah intensif, tanah diolah dengan sempurna yang mengakibatkan tanah menjadi gembur dan pori-pori tanah menjadi lebih terbuka sehingga laju infiltrasi tanah menjadi lebih cepat. Menurut Utomo (2015), penambahan mulsa gulma dan sisa tanaman sebelumnya pada sistem olah tanah konservasi menyebabkan peningkatan kelembaban tanah dan evaporasi air menurun. Selain itu pada sistem olah tanah jangka panjang, pada kedalaman 0-30 $\mathrm{cm}$ tanah pada perlakuan olah tanah konservasi lebih keras dibandingkan dengan olah tanah intensif.

Tabel 4. Pengaruh sistem olah tanah dan pemupukan N terhadap Laju Infiltrasi Tanah.

\begin{tabular}{ccc}
\hline & Perlakuan & Laju Infiltrasi $\left(\mathrm{cm} \mathrm{jam}^{-1}\right)$ \\
\hline \multirow{2}{*}{ Sistem olah tanah } & Olah Tanah Intensif & $56,61 \mathrm{c}$ \\
& Olah Tanah Minimum & $36,81 \mathrm{~b}$ \\
& Tanpa Olah Tanah & $25,35 \mathrm{a}$ \\
\hline BNT 5\% & 4,46 \\
\hline \multirow{2}{*}{ Pemupukan Nitrogen } & $0 \mathrm{~kg} \mathrm{~N} \mathrm{ha}^{-1}$ & $34,52 \mathrm{~b}$ \\
& $200 \mathrm{~kg} \mathrm{~N} \mathrm{ha}^{-1}$ & $44,66 \mathrm{a}$ \\
\hline BNT 5\% & & 5,32 \\
\hline
\end{tabular}

Keterangan : Nilai tengah pada kolom yang diikuti huruf yang sama tidak berbeda nyata menurut uji BNT pada taraf 5\%. 
Kecepatan laju infiltrasi pada $0 \mathrm{~kg} \mathrm{Nha}^{-1}$ sebesar $34,52 \mathrm{~cm} \mathrm{jam}^{-1}$ dan pada $200 \mathrm{~kg} \mathrm{~N} \mathrm{ha}^{-1}$ sebesar 44,66 $\mathrm{cm} \mathrm{jam}^{-1}$. Pada pemupukkan $200 \mathrm{~kg} \mathrm{~N} \mathrm{ha}^{-1}$ nilai laju infiltrasinya lebih cepat dibandingkan tanpa pemupukan. Hal ini dapat disebabkan karena pemberian hara nitrogen dapat meningkatkan populasi organisme tanah. Peningkatan populasi organisme dalam tanah dapat menyebabkan rongga atau pori tanah yang terbentuk meningkat akibat dari aktivitas biota tanah tersebut sehingga laju infiltrasi tanahmeningkat (Asdak, 2002).

Pengukuran laju infiltrasi konstan dilakukan ketika kecepatan air di dalam ringmenjadi konstan, dapat dilihat dari perhitungan waktu dan penurunan air pada ring yang tidak mengalami perubahan atau penurunan lagi. Interval waktu pengukuran laju infiltrasi tersebut dihitung dalam menit atau jam, tergantung dari tekstur tanahnya.Jumlah waktu yang dibutuhkan dari setiap perlakuan untuk mencapai lajuinfiltrasi konstan sangat beragam. Jadi jika pemberian air lebih dari banyaknya air yang masuk kedalam tanah di setiap perlakuan maka akan terjadi run off.

\section{Klasifikasi Laju Infiltrasi}

Berdasarkan klasifikasi laju infiltrasi pada Tabel 5 menurut U.S Soil Conservation, setiap perlakuan menunjukkan klasifikasi laju infiltrasi konstan yang berbeda. Tabel 6 menununjukan hasil klasifikasi laju infiltrasi pada perlakuan N0T1 dan N2T1 diperoleh klasifikasi laju infiltrasi cepat. Pada perlakuan N0T2 dan N2T3 diperoleh klasifikasi laju infiltrasi sedang. Pada perlakuan N0T3 diperoleh klasifikasi laju infiltrasi agak lambat. Pada perlakuan N0T3 diperoleh klasifikasi laju infiltrasi agak lambat. Pada perlakuan N2T1 diperoleh klasifikasi laju infiltrasi cepat.
Tabel 5. Klasifikasi Laju Infiltrasi U.S Soil Conservation dalam Harimi

\begin{tabular}{ccc}
\hline Kelas & Klasifikasi & Laju Infiltrasi $\left(\mathrm{cm} \mathrm{jam}^{-1}\right)$ \\
\hline 0 & Sangat Lambat & $<1$ \\
1 & Lambat & $05-10$ \\
2 & Agak Lambat & $10-20$ \\
3 & Sedang & $20-40$ \\
4 & Agak Cepat & $40-50$ \\
5 & Cepat & $50-65$ \\
6 & Sangat Cepat & $>65$ \\
\hline
\end{tabular}

(U.S Soil Conservation dalam Harimi, 2018)

Tabel 6. Hasil klasifikasi laju infiltrasi pada setiap perlakuan

\begin{tabular}{ccc}
\hline Perlakuan & $\begin{array}{c}\text { Rata-rata Laju Infiltrasi } \\
\text { Konstan }\left(\mathrm{cm} \mathrm{jam}^{-1}\right)\end{array}$ & $\begin{array}{c}\text { Klasifikasi } \\
\text { Laju Infiltrasi }\end{array}$ \\
\hline N0T1 & 50,89 & Cepat \\
N0T2 & 33,07 & Sedang \\
N0T3 & 19,59 & Agak Lambat \\
N2T1 & 62,33 & Cepat \\
N2T2 & 40,54 & Agak Cepat \\
N2T3 & 31,11 & Sedang \\
\hline
\end{tabular}

Keterangan : N0 $=0 \mathrm{~kg} \mathrm{~N} \mathrm{ha}^{-1}, \mathrm{~N} 1=200 \mathrm{~kg} \mathrm{~N} \mathrm{ha}^{-1}, \mathrm{~T} 1=$ Olah tanah intensif, $\mathrm{T} 2=$ Olah tanah minimum, T3 = Tanpa olah tanah.

Perbedaan klasifikasi ini terjadi karena setiap perlakuan memiliki pengaruh yang signifikan terhadap nilai laju infiltrasi tanah. Hal tersebut sejalan dengan pernyataan Zhipeng dkk(2017) bahwasannya olah tanah memilikidampak besar pada karakteristik infiltrasi. Kondisi struktur tanah pada lahan cenderung remah, jadi padaklasifikasi laju infiltrasi tersebut tidak terdapat klasifikasi tanah pada kelas yang lambat.

Bahan organik juga mempengaruhi kecepatan laju infiltrasi tanah. Bahan organik pada penelitian ini memiliki pengaruh nyata pada perlakuan olah tanah pemupukan nitrogen, dan diduga hal tersebut menyebabkan tanah dapat menahan air lebih banyak. Hal tersebut didukung oleh pernyataan Utomo dkk(2016) bahwa bahan organik tanah memiliki pengaruh positif terhadap sifat kimia, fisik dan biologi 
Tabel 7. Jumlah air yang ditambahkan sebelum mencapai laju infiltrasi konstan

\begin{tabular}{cc}
\hline Perlakuan & $\begin{array}{c}\text { Rata-rata jumlah air yang } \\
\text { ditambahkan }(\mathrm{cm})\end{array}$ \\
\hline N0T1 & 46,7 \\
N0T2 & 32,1 \\
N0T3 & 19,2 \\
N2T1 & 53,7 \\
N2T2 & 37,4 \\
N2T3 & 29,0 \\
\hline
\end{tabular}

Keterangan : $\mathrm{N} 0=0 \mathrm{~kg} \mathrm{~N} \mathrm{ha}^{-1}, \mathrm{~N} 1=200 \mathrm{~kg} \mathrm{~N} \mathrm{ha}^{-1}, \mathrm{~T} 1=\mathrm{Olah}$ tanah intensif, $\mathrm{T} 2=$ Olah tanah minimum, $\mathrm{T} 3=$ Tanpa olah tanah.

dari tanah. Jumlah bahan organik di dalam tanah diperkirakan hanya berkisar 5\% dari total volume tanah, tetapi berpengaruh terhadap sebagian besar sifat tanah. Pengaruh menguntungkan dari bahan organik tanah diantaranya meningkatkan struktur dan agregasi tanah, meningkatkan presentasi ruang pori tanah, dan meningkatkan kapasitas tanah untuk menahan air, juga meningkatkan kekuatan air terikat di dalam tanah.

Selain itu, tanah pada penelitian inimemiliki tekstur liat. Tanah-tanah dengan kandungan klei/liat tinggi memiliki ukuranpartikel primer sangat kecil dan posisinya saling berdekatan. Konsekuensinya,tanah dengan klei tinggi mempunyai sedikit pori-pori kasar (makro) dan didominasi oleh pori mikro sehingga air yang melewati tanah lebih lambat. Oleh karena itu, klasifikasi laju infiltrasi pada setiap perlakuan berada pada kelas agak lambat-cepat.

\section{Sorpsivitas}

Sorpsivitas adalah jumlah air yang ditambahkan untuk mencapai titik konstan lajuinfiltrasi. Nilai sorpsivitas tersebut dapat diperoleh dari borang pengisian laju infiltrasi. Setiap perlakuanmemiliki jumlah air yangditambahkan yang berbeda. Pada Tabel 7, perbedaan jumlah air tersebut karena titik konstan laju infiltrasi dari setiap perlakuan juga berbeda. Perlakuan tanpa pemupupukan nitrogendengan olah tanah intensif (N0T1) memiliki rata-ratajumlah air yang ditambahkan sebesar 46,73 $\mathrm{cm} \mathrm{jam}^{-1}$. Perlakuan tanpa pemupukan nitrogendengan olah tanah minimum (N0T2) memiliki rata-rata jumlah air yang ditambahkan sebesar 32,10 $\mathrm{cm} \mathrm{jam}^{-1}$. Perlakuan tanpa pemupukan nitrogen dengan tanpa olah tanah (N0T3) memiliki rata-rata jumlah air yang ditambahkan sebesar 19,20 $\mathrm{cm} \mathrm{jam}^{-1}$. Perlakuan penambahan pupuk nitrogen $200 \mathrm{~kg} \mathrm{~N} \mathrm{ha}^{-1}$ dengan olah tanah intensif(N2T1) memiliki rata-rata jumlah airyang ditambahkan sebesar 53,70 $\mathrm{cm} \mathrm{jam}^{-1}$. Perlakuan penambahan pupuk nitrogen $200 \mathrm{~kg} \mathrm{~N} \mathrm{ha}^{-1}$ dengan olah tanah minimum (N2T2) memiliki rata-rata jumlah air yang ditambahkan sebesar 37,40 $\mathrm{cm}$ jam $^{-1}$. Perlakuan

Tabel 8. Nilai sorptivitas berdasarkan pendekatan teori

\begin{tabular}{ccccc}
\hline Perlakuan & $\begin{array}{c}\text { Rerata } \\
\text { Porositas } \\
\text { (\% Volume })\end{array}$ & $\begin{array}{c}\text { Rerata KA } \\
\text { Volumetrik } \\
(\%)\end{array}$ & $\begin{array}{c}\text { Sorpsivitas } \\
(\%)\end{array}$ & $\begin{array}{c}\text { Sorpsivitas (\%) x 100 mm } \\
(\mathrm{mm})\end{array}$ \\
\hline N0T1 & 58,85 & 34,24 & 24,61 & 24,61 \\
N0T2 & 61,67 & 33,77 & 27,90 & 27,90 \\
N0T3 & 59,25 & 37,83 & 21,42 & 21,42 \\
N2T1 & 59,61 & 34,68 & 24,93 & 18,93 \\
N2T2 & 57,71 & 39,06 & 18,65 & 23,64 \\
N2T3 & 58,99 & 35,34 & 23,64 & \\
\hline
\end{tabular}

Keterangan : $\mathrm{N} 0=0 \mathrm{~kg} \mathrm{~N} \mathrm{ha}^{-1}, \mathrm{~N} 1=200 \mathrm{~kg} \mathrm{~N} \mathrm{ha}^{-1}, \mathrm{~T} 1=$ Olah tanah intensif, $\mathrm{T} 2=$ Olah tanah minimum, T3 = Tanpa olah tanah. 
penambahan pupuk nitrogen $200 \mathrm{~kg} \mathrm{~N} \mathrm{ha}^{-1}$ dengan tanpa olah tanah (N2T3) memiliki rata-rata jumlah air yang ditambahkan sebesar 29,03 $\mathrm{cm} \mathrm{jam}^{-1}$.

Nilai sorptivitas dapat diperolehdengan persamaan Sorptivitas $(S)=$ Porositas $(\eta)-$ kadar air volumetrik ( $\theta$ awal). Nilai sorpsivitas dari persamaan tersebut dapat dilihat pada Tabel 8.

Nilai sorpsivitas berbeda dikarenakan Tortuosity factor atau faktorkelengkungan pori tanah yang menyebabkan air yang masuk ke dalam tanah tidaklangsung terserap. Dengan demikian nilai laju infiltrasi yang diperoleh dariborang pengisian laju infiltrasi dan perhitungan berdasarkan teori berbeda hasilnya. Namun perbedaan yang tidak signifikan antara nilai sorptivitas di borang dan dari hitungan teori menunjukan bahwa nilai sorptivitas yang didapatkan masih sesuai atau tidak berbeda nyata. Sorpsivitas tertinggi terdapat pada perlakuan olah tanah intensif dan terendah pada perlakuan tanpa olah tanah.

\section{KESIMPULAN}

Kesimpulan yang didapat adalah (1) Laju infiltrasi selama 60 menit pada sitem olah tanah intensif(OTI) lebih tinggi dibanding sistem olah tanah lainnya (2) Perlakuan aplikasi pemupukan nitrogen berpengaruh terhadap meningkatnya laju infiltrasi. (3) Tidak terdapat interaksi antara sistem olah tanah dengan pemupukan nitrogen terhadap laju infiltrasi.

\section{DAFTAR PUSTAKA}

Afandi. 2019. Metode Analisis Fisika Tanah. Anugrah Utama Raharja. Bandar Lampung.
Arsyad, S. 2010. Konservasi Tanah dan Air. Edisi Kedua,IPB. Press. Bogor.

Asdak C. 2002. Hidrologi dan Pengelolaan Daerah Aliran Sungai. Gadjah Mada University Press. Yogyakarta

BPS (Badan Pusat Statistik). 2015. Produksi Jagung (ton). http://bps.go.id. diakses 23 Maret 2019 pukul 21.00.

Diara, W.I. 2017. Skripsi “Degradasi Kandungan COrganik dan Hara Makro pada Lahan Sawah dengan Sistem Pertanian Konvensional". Agroteknologi Universitas Udayana. Bali.

FAO. 1987. Framework for Land Evolution. FAO Soils Bulletin. Soil Resources Management and Conservation Service Land and Water Development Division.

Harimi, N. 2018. Skripsi "Pengaruh Tipe Vegetasi Tumbuhan Terhadap Laju Infiltrasi di Kawasan Geothermalie Suum Kecamatan Mesjid Raya Kabupaten Aceh Besar Sebagai Referensi Matakuliah Ekologi Tumbuhan". Universitas Islam Negeri ArRaniry. Banda Aceh.

Mulyani, M. 2003. Pupuk dan Cara Pemupukan. Rineka Cipta. Jakarta.174 hlm.

Rachman, A., Ai Dariah, Edi Husein. 2004. Olah Tanah Konservasi. Pusat

Penelitian dan Penelitian Tanah dan Agroklimat. Bogor. $282 \mathrm{hlm}$.

Subandi, 2003. Peranan Benih Berkualitas Varietas Unggul Dalam Meningkatkan Produksi 
Jagung. Makalah Disampaikan pada acara "Sosialisasi Produksi Benih Jagung Unggul Nasional dan Distribusinya" Balitsereal-Maros: 15-21 Desember 2003.

Utomo, M. 2015. Tanpa Olah Tanah: Teknologi Pengelolaan Pertanian Lahan Kering. Lembaga Penelitian Universitas Lampung. Bandar Lampung. 157 hlm.
Utomo, M., Sudarsono, Bujang Rusman, T. Sabrina, J. Lumbanraja, Wawan. 2016. Ilmu Tanah : Dasar-dasar dan Pengelolaan. Jakarta: Prenadamedia Group. $434 \mathrm{hlm}$.

Zhipeng, Liu., Ma Donghaob, Hu Weic, Li Xuelina. 2018. Land use dependent variation of soil water infiltration characteristics and their scalespecific controls. Soil \& Tillage Research 178 (2018) : 139-149. 